N. K. Kouassi

Centre National de Recherche Agronomique (CNRA), Laboratoire Central de Biotechnologies, Côte d'Ivoire

\author{
P. N'Guessan \\ CNRA, Station de Recherche de Man, Côte d'Ivoire
}

L. Albar

Institut de Recherche pour le Développement (IRD), France

C. M. Fauquet

ILTAB, Donald Danforth Plant Science Center, St. Louis, MO, USA

C. Brugidou

IRD, France

\title{
Distribution and Characterization of Rice yellow mottle virus: A Threat to African Farmers
}

Africa produces only $2.7 \%$ of the world's rice and is the second-largest riceimporting region in the world $(6.5 \mathrm{Mt}$ in 2003). This amount represents about $25 \%$ of the world rice importation (40). With an average of $2 \mathrm{t} / \mathrm{ha}$, excluding Egypt, rice production in Africa remains significantly below the world average (Asia $3.8 \mathrm{t} / \mathrm{ha}$, Latin America 3.0 t/ha, United States 7.0 t/ha; Food and Agriculture Organization of the United Nations [FAO], published online). Insects and diseases are the two major constraints limiting rice production in Africa and Asia. Of all the rice diseases, the one caused by the Rice yellow mottle virus (RYMV), discovered in Kenya in 1970, is one of the most damaging in Africa. RYMV has been reported in many countries in East and West Africa, where in some cases whole fields have been devastated. RYMV has only been reported from the African continent and is endemic in every country where it has been reported.

RYMV is a member of the genus Sobemovirus and possesses all the characteristic biophysical and biological properties of the members of the genus. The major insect vectors are chrysomelids, which play

Corresponding author: C. Brugidou, Institut de Recherche pour le Développement (IRD), BP 64501, 34394 Montpellier cedex 5, France

E-mail: christophe.brugidou@mpl.ird.fr

This paper is dedicated to the memory of our colleague and friend, co-author Dr. Placide N'Guessan.

DOI: 10.1094/PD-89-0124

(C) 2005 The American Phytopathological Society an essential role in primary infection, while secondary infection is due mainly to plant-to-plant contact. The virus particles are stable in infected dried leaves. Limitations to the spread of the virus include restricted mobility of the insect vectors, a limited host range, and absence of seed transmission. Partially resistant and highly resistant varieties have been identified, but currently the disease is not controlled adequately, and its incidence is increasing significantly in Africa.

Due to the importance of rice as a staple food, the scientific community is active in studying the virus and the resistant mechanisms in rice. At the Institut de Recherche pour le Developpement (IRD) and the International Laboratory for Tropical Agricultural Biotechnology (ILTAB), different tools, such as RYMV polyclonal and monoclonal antibodies, have been produced for RYMV detection; and a series of studies has been initiated for a better understanding of the virus-host interactions. The synthesis of an infectious clone, the sequencing of many isolates of the virus, and structural studies of virus particles permitted a study of the function of the different viral proteins and an increased understanding of the virus cycle. African virologists also have initiated studies on the epidemiology of the RYMV, mainly the virulence and variability of virus strains collected throughout Africa $(36,45)$. The relationships between genetic variability of the virus and geographical distances have been studied (19).

Currently, phytopathologists are working in the field to better assess the agronomic impact of the virus $(36,61,62)$. Breeders and geneticists at IRD and West
African Rice Development Association (WARDA) in Côte d'Ivoire are working together to identify and isolate natural resistance genes $(6,41)$. The International Institute for Tropical Agriculture (IITA) in Nigeria undertook breeding programs in Africa. Molecular biologists are offering new ways of controlling the disease through production of transgenic rice plants $(37,52)$. This article is intended to provide a review of the disease and give an update on recent research results. The disease's impact on rice production in Africa, its distribution, symptomatology, and epidemiology, the physical and genetic characteristics of the virus, and resistance mechanisms and breeding efforts for resistance will be discussed.

\section{Impact of RYMV on Rice Production}

Disease incidence. RYMV was first reported in 1970 in the Nyanza province of western Kenya near Lake Victoria (13). Subsequently, the virus was described in many different countries in West, Central, and East Africa (Fig. 1). It was described in 1976 in Liberia, Nigeria, Sierra Leone, and Tanzania $(55,60)$. In the following year, RYMV was reported at several locations in Côte d'Ivoire (Ivory Coast) (22), and in 1980 in Ghana and at Koba in Guinea (56). By the late 1980s, RYMV had been identified in Niger, Burkina Faso, and Mali, as well as in Malawi (34) and Rwanda (10), and it was described in Madagascar in 1989. On this island, the severity of the infection was such that within a few years, rice cultivation was abandoned in Marovoay and at Lake Alaotra (58). RYMV also has been re- 
corded in Gambia, Guinea Bissau, Senegal, Mauritania (9), and Zanzibar (7). Most recently, the virus has been reported in Cameroon and Chad (Central Africa) (66).

RYMV's known occurrence is restricted to Africa. RYMV was first found to infect only lowland rice in West Africa (59); however, in 1987, it was also reported for the first time on upland cultivation (10). During a survey in 1983 and 1986, 75\% of the total cultivated area of rice in the Sahel was reported to be contaminated, $40 \%$ in the Sudan savanna, $18 \%$ in Guinea savanna, and $7.5 \%$ in the tropical rain forest (9). Incidence and severity of the disease appeared to depend on the rice varieties, environment, and vegetation zones (9). Some examples of the incidence of RYMV for individual countries and locations are presented in Table 1.

Economic importance. Early reports did not quantitatively estimate the damage caused by RYMV on rice production. The economic impact of RYMV is difficult to evaluate due to the influence of many factors such as environment, vegetation zone, and rice varieties. Yield losses fluctuate between 10 and $100 \%$, depending on plant age prior to infection, susceptibility of the rice variety, and environmental factors (Table 1). A survey from the "Office du Niger" in Mali showed yield losses up to $70 \%$ following RYMV infections. Yield reduction ranging from 58 to $68 \%$ was reported in 1986 in the Republic of Niger (57). Another study conducted by Taylor (65) indicates yield losses from 82 to $97 \%$ on varieties PN623-3, Tox 516-12-SLR, ROK3, ROK15, and IR65.

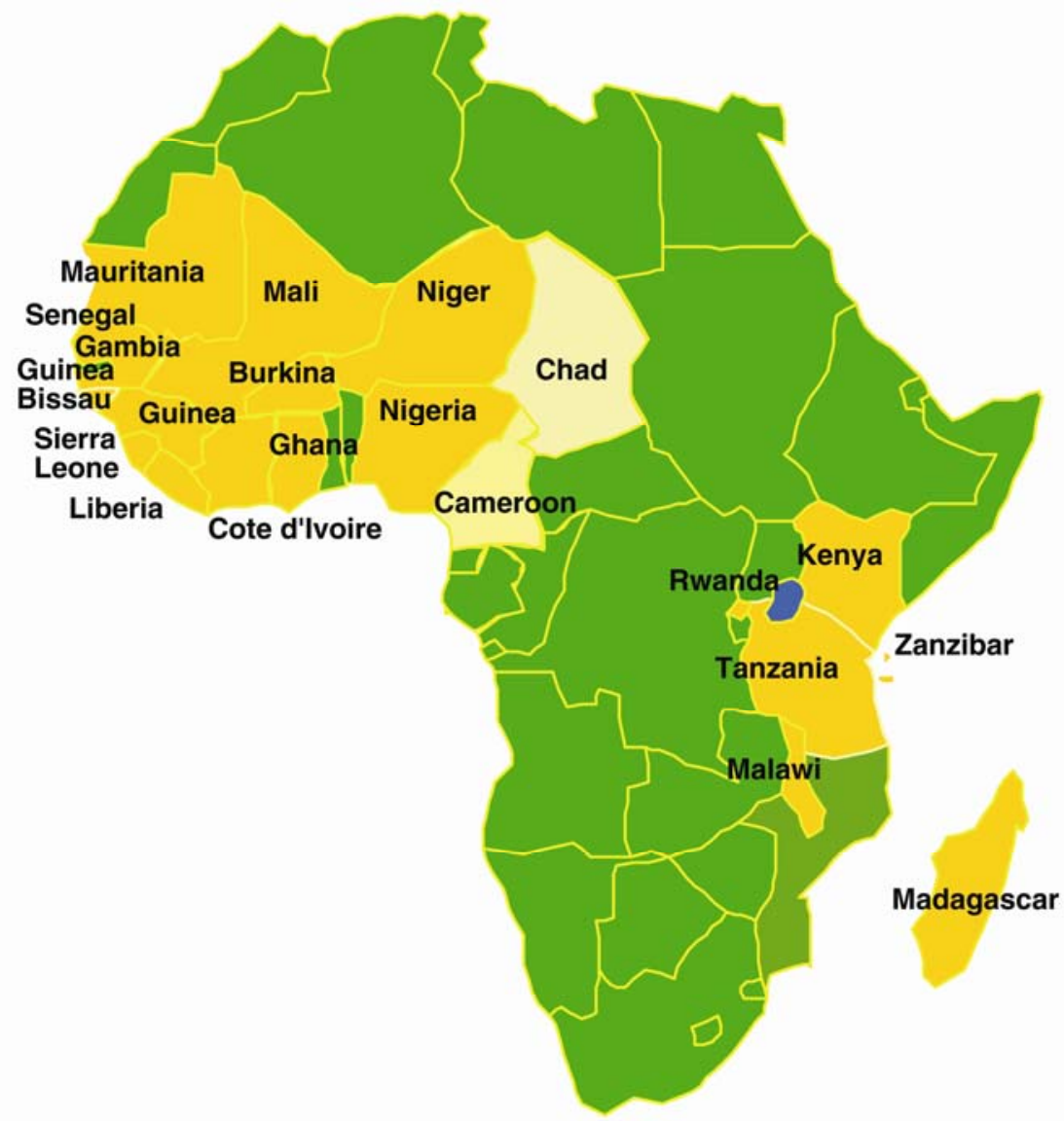

Fig. 1. Distribution of Rice yellow mottle virus (RYMV) in Africa. Countries where the virus has been isolated appear in yellow. RYMV was first reported in Kenya in 1970; in Liberia, Nigeria, Sierra Leone, and Tanzania in 1976; in the Ivory Coast in 1977; in Ghana and Guinea in 1980; in Niger, Burkina Faso, Mali, Malawi, and Rwanda in 1987; in Madagascar in 1989; in Gambia, Guinea Bissau, Senegal, and Mauritania in 1991; in Zanzibar in 1995; and in Cameroon and Chad in 2000.

Table 1. Incidence of Rice yellow mottle virus (RYMV) in relationship to rice environment and vegetation zones, recorded during a 1983 to 1986 survey, based on location of rice fields in West Africa (9)

\begin{tabular}{|c|c|c|c|}
\hline Vegetation zone & Location (country) ${ }^{\mathbf{a}}$ & Rice environment (rice variety) & $\begin{array}{c}\text { RYMV } \\
\text { incidence }\end{array}$ \\
\hline Sahel & $\begin{array}{l}\text { Libore, Saga, Sadia (NE) } \\
\text { Mpourie \& Kaedi (MR) } \\
\text { Mopti, Gao (ML) } \\
\text { Kolo, Daikena (NE) } \\
\text { Fanaye, Richard Toll, Dagana (SN) }\end{array}$ & $\begin{array}{l}\text { Lowland (IR40, Tchounchen 22) } \\
\text { Lowland (Jaya) } \\
\text { Floating (Khao Gaew, BKN 6323) } \\
\text { Floating (Ikong Pao, BR51-46-5) }\end{array}$ & $\begin{array}{c}80-100 \% \\
25-55 \% \\
5-15 \% \\
10 \%\end{array}$ \\
\hline $\begin{array}{l}\text { Sudan } \\
\text { savanna }\end{array}$ & $\begin{array}{l}\text { Odienné (CI), Sefa (SN) } \\
\text { Bobodioulasso (BF), Sikasso (ML) } \\
\text { Kogoni, Segou (ML) } \\
\text { Banfora (BF), Birnin Kebbi (NG) }\end{array}$ & $\begin{array}{l}\text { Upland rice } \\
\text { Lowland rice } \\
\text { Floating rice }\end{array}$ & $\begin{array}{c}0-40 \% \\
25-55 \% \\
6-15 \%\end{array}$ \\
\hline $\begin{array}{l}\text { Guinea } \\
\text { savanna }\end{array}$ & $\begin{array}{l}\text { Badeggi (NG), Kindia (GN) } \\
\text { Contouboel (GW) } \\
\text { Guekedou (GN), Bouaké (CI) } \\
\text { Carboxanque (GW) } \\
\text { Rokupr (SL), Sanfonia (GN) } \\
\text { Carboxanque (GW) } \\
\text { Kankan (GN), Jenoi (GA) }\end{array}$ & $\begin{array}{l}\text { Lowland rice } \\
\text { Upland rice } \\
\text { Mangrove } \\
\text { Floating rice (DA29, RD5, DM 16) }\end{array}$ & $\begin{array}{l}20-48 \% \\
0-10 \% \\
2-8 \%\end{array}$ \\
\hline $\begin{array}{l}\text { Tropical } \\
\text { rainforest }\end{array}$ & $\begin{array}{l}\text { Dabou (CI), Kpong (GH) } \\
\text { Ibadan (NG), Suakoko (LR) } \\
\text { Suakoko (LR), Ikenne (NG) } \\
\text { Tombokro (CI) } \\
\text { Warri (NG) }\end{array}$ & $\begin{array}{l}\text { Lowland (IRAT 112, C22, BG 90-2) } \\
\text { Upland rice (UPL Ri5, IR 52) } \\
\text { Mangrove }\end{array}$ & $\begin{array}{l}5-10 \% \\
0-40 \% \\
0-10 \%\end{array}$ \\
\hline
\end{tabular}

${ }^{a}$ NE: Niger; MR: Mauritania; ML: Mali; SN: Senegal; CI: Côte d'Ivoire; BF: Burkina Faso; GH: Ghana; GN: Guinea; GW: Guinea Bissau; SL: Sierra Leone; GA: Gambia; LR: Liberia. 


\section{Characteristics of the Disease}

Symptomatology. The appearance and intensity of symptoms may vary among different rice genotypes, but the following are those most generally observed. Approximately 1 to 2 weeks after inoculation, small, yellow-green, oblong to linear spots appear at the bases of the youngest, systemically infected leaves. With time, these spots elongate parallel to the vein, while slightly darker patches develop in the center of these yellow streaks (Fig. 2A and B). Yellow or orange discoloration of the older leaves also occurs (Fig. 2C). Leaves formed later are mottled and often spirally twisted $(11,13)$. With some varieties, the leaves become narrow and the infected rice fields acquire a general yellow-orange shade. The disease causes stunting and reduced tillering of rice and is associated with crinkling, mottling, malformation, and incomplete emergence of the panicles, resulting in sterility and significantly reduced yields $(9,13)$.

Severity of infection and resulting yield losses depend on the age of infected plants. If plants are infected within 20 days after planting, they will exhibit most of the symptoms described above, may stop
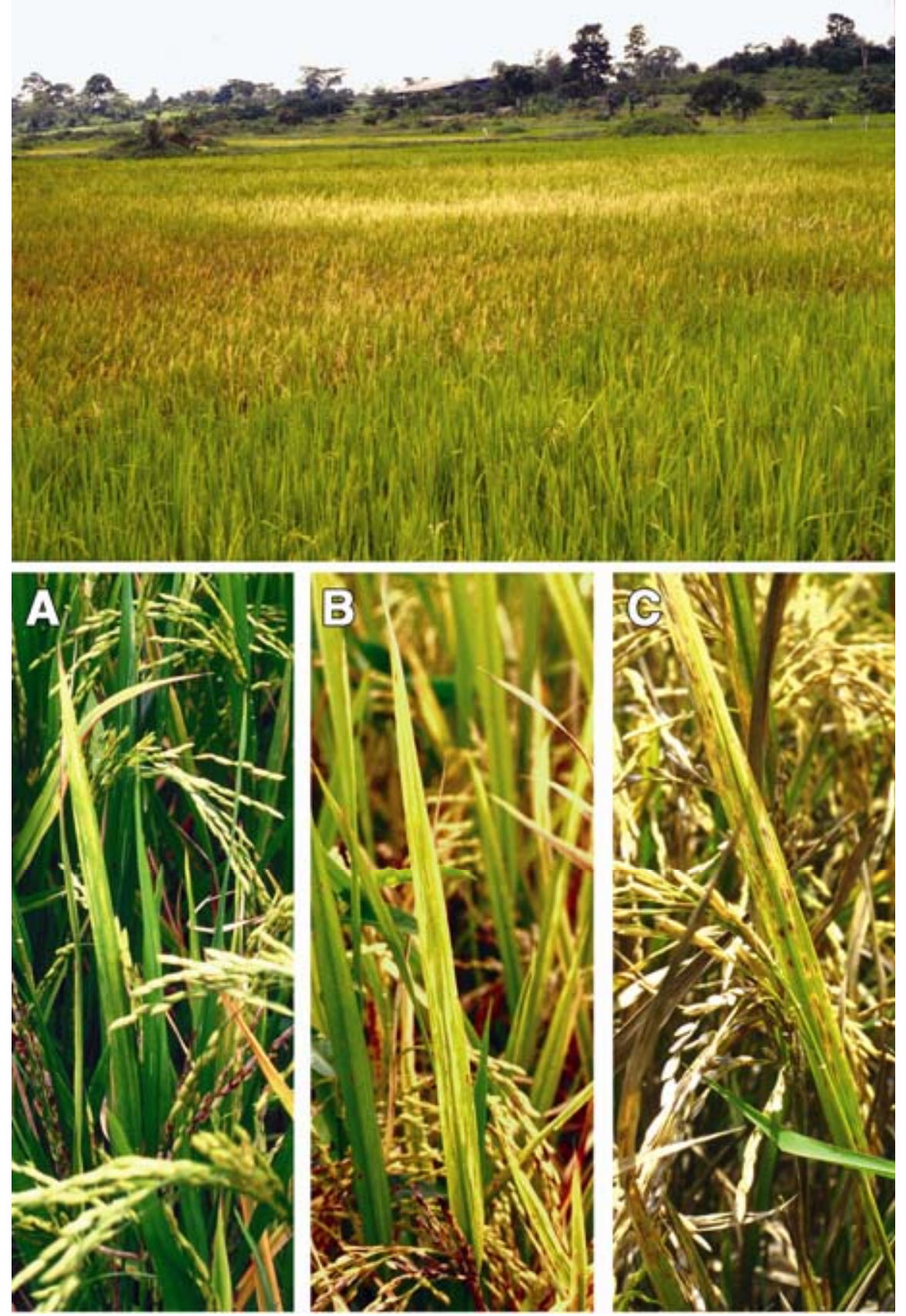

Fig. 2. Rice yellow mottle virus (RYMV) symptoms in infected rice field, Ivory Coast (Bouaké, 1995). A, Yellow or discolored and elongated spots parallel to the veins appear on rice leaves, with incomplete emergence of the panicle. Symptom evolution during flowering: A, symptoms appear during development of panicles; B, leaves and panicles turn yellow; C, panicles turn brown before seed maturation. growing, and eventually die. If the infection occurs from 20 to 50 days after planting, the plant will continue to grow but will be stunted. These plants will have yellow stripes and spots on the new leaves (Fig. 2C) and will produce flowers and seeds with variable losses. If the infection occurs 50 days or more after planting, the infected plants will grow normally, exhibit only faint yellow stripes, and flower and seeds will be normal. In some varieties, orange discoloration of the older leaves may appear, but in more resistant varieties, the symptoms may not be distinctive.

Epidemiology. The hosts of the virus are restricted to the Graminea and Eragrostidae families. The most commonly cited primary host is the perennial, wild species of rhizomatous rice, Oryza longistaminata Chev. \& Roech., often found at the edges of small ponds and in permanently flooded swamps. O. barthii Chev. and $O$. glaberrima Steud. have also been found to be susceptible to RYMV and could therefore be possible alternative hosts for RYMV (9). Other Oryza species and some nonrice wild species have also been found to be susceptible to RYMV $(1,2,9,13,22,46)$. Therefore, these species could have potentially acted as reservoirs for the virus that spread to the Asian rice (O. sativa) when it was introduced into Africa a few centuries ago. O. sativa is an excellent host for the virus, and as a result of the intensification of rice culture and introduction of susceptible Asian varieties in the African continent in the 1960s, RYMV epidemics have occurred.

The virus is transmissible by insect vectors. Most of the insect vectors belong to the coleopteran order, especially to Chrysomelidae family, such as Sesselia pusilla (Gerst.) (Galerucinae), Chaetocnema pulla (Chapuis) (Halticinae), Trichispa sericea (Guérin) (Hispinae), and Dicladispa (Chrysispa) viridicyanea (Kraatz) (Hispinae) $(1,2,12,13)$. The grasshopper Conocephalus merumontanus (Sjost.) also is recorded as a possible vector (1). The virus can be transmitted by farm implements such as sickles (2) used in harvesting rice, by contaminated hands (1), or by tight contact between plants during planting out. In the laboratory, the virus also is mechanically transmitted through sap from infected leaves with the aid of Carborundum $(13,22)$. Recent studies in Mali indicated that RYMV is also transmitted by cows, donkeys, and grass rats through mechanical contact (grazing and trampling) (61). RYMV can also be transmitted by windmediated leaf contact (61) and through guttation fluid (2) and irrigation water (1).

The virus has been recovered from roots of diseased plants $(11,55)$. RYMV has not been demonstrated to be seed transmitted. It was detected in all infected seeds parts (glumella, endosperm, and embryo), but its infectivity decreased throughout the process of seed formation (35). 
The epidemiology of the virus can be summarized as follows (Fig. 3): as soon as the rice is planted in the field, insect vectors leave the wild rice or other RYMV reservoirs, invade the newly planted rice, and transmit the virus. Secondary spread takes place by wind-mediated contact between the leaves and other mechanical mechanisms. In lowland rice fields, the permanent presence of alternative hosts and the regrowths and/or the interseason rice plants are presumably responsible for the "green bridge" allowing continual survival of the virus. The destruction of virus reservoirs by fire during the dry season, removal of rice regrowths, and the use of chemical treatment against insect vectors can dramatically reduce primary, and subsequently, secondary infections (2).

\section{Characteristics of RYMV Particles}

Purification. RYMV particles are easily purified from fresh or deep-frozen young rice leaves harvested from 14 days after infection $(11,13)$. Leaves are ground in liquid nitrogen and homogenized in $0.1 \mathrm{M}$ phosphate buffer, $\mathrm{pH}$ 5.0. Further purification can be performed through a 10 to $40 \%$ sucrose gradient by centrifugation at 3,000 $\times g$ for $2 \mathrm{~h}$. The concentration of the virus preparation is estimated by spectrophotometer and is calculated using an extinction coefficient of 6.5. The virus yields from infected rice plants vary considerably from 1 to $6 \mathrm{~g}$ of virus per $\mathrm{kg}$ of infected leaves $(11,23)$, and purified virus particles can be easily visualized by electron microscopy (Fig. 4A).

Structure. RYMV virions are icosahedral particles and form a single band when centrifuged in $\mathrm{CsCl}\left(1.36 \mathrm{~g} / \mathrm{cm}^{3}\right)$. The particles consist of approximately $20 \%$ RNA and $80 \%$ protein and contain no lipids or carbohydrates (13). The virus capsid is constructed from 180 copies of $26-\mathrm{kDa}$ coat protein $(\mathrm{CP})$ subunits assembled in a $\mathrm{T}=3$ icosahedral structure (Fig. 4B) stabilized by divalent cations $\left(\mathrm{Ca}^{2+}\right)$, $\mathrm{pH}-\mathrm{de}-$ pendent protein-protein interaction, and salt bridges between protein and RNA (30). The structure of RYMV has been refined to $2.8 \AA$ resolution by X-ray crystallography (Fig. 4C) (54).

Genome organization. The genome of RYMV is a single-stranded, linear, positive-sense RNA nonpolyadenylated with a molecular mass of $1.4 \times 10^{6}$ Da. Primarily, sequence of the genome of RYMV (Mali strain) was found to be 4,450 nucleotides (nt) long (43; accession no. AJ279920) and $4,451 \mathrm{nt}$ for the Nigerian strain (accession no. U23142). Recently, a new genomic organization of $4,452 \mathrm{nt}$ has been determined by extensive sequencing of various isolates (19). Thus, the coding sequences from $5^{\prime}$ to $3^{\prime}$ are as follows: ORF1, ORF2a, ORF2b, and ORF4 (Fig. 5). ORF1 codes for a protein of 157 aa (17.8 kDa). The overlapping ORF2a and
ORF2b, considered to be Cocksfoot mosaic virus-like (CfMV) (64), encode for a polyprotein (serine protease like, VPg, RNAdependent RNA polymerase), with the Nterminal part encoded by ORF2a and the $\mathrm{C}$ terminal half by ORF2b. The ORF2b is supposed to be translated as part of the polyprotein by a -1 ribosomal frame shifting mechanism described with the CfMV (38). The ORF4 starts at nucleotide 3,447 , overlaps by $160 \mathrm{nt}$ of the C-terminal of ORF2b, and ends at nucleotide 4,166. This ORF4 encodes for a coat protein of 239 aa (26 kDa). The N-terminal first 3 to 22 aa sequence of ORF4 contains a putative nuclear localization signal (NLS), similar to the bipartite nuclear targeting consensus (43). A subgenomic single-stranded RNA of about 1,000 nt has been isolated from RYMV- and SBMV-infected plants but not from particles $(29,43)$. A low-molecularweight RNA of $220 \mathrm{nt}$ has also been isolated from the virion of some RYMV isolates (63). This associated small RNA shows a strong structural homology with the satellite RNA of the Canadian Lucerne transient streak virus, a sobemovirus (51). In order to better understand the replication process, gene expression, and the function of its proteins, full-length cDNA clones of RYMV and infectious transcripts have been obtained for an Ivory Coast isolate (RYMVCI1, accession no. AJ279902) (17).

The function of the P1 protein has been investigated through expression of wild

\section{Primary infection by beetles : Chaetocnema pulla}

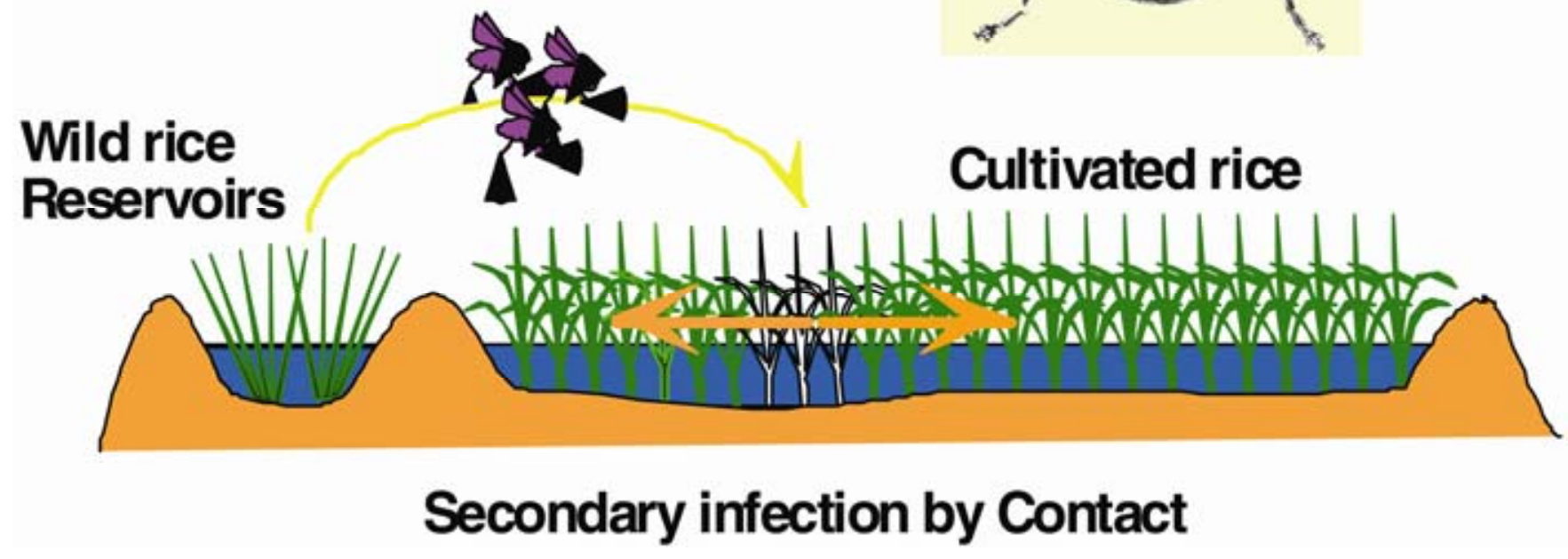

Fig. 3. Rice yellow mottle virus (RYMV) epidemiology. Coleopterans carrying RYMV transmit virus from wild rice (natural host) to healthy rice plants at different locations in the field, as soon as rice is planted. Secondary spread occurs by mechanical contact between infected and healthy leaves. 
type and mutant $\mathrm{P} 1$ in vitro and in vivo. $\mathrm{P} 1$ is required for infection of the plant and for virus spread (16) and also in suppressing virus-induced gene silencing (VIGS) (69). The CP gene is required for full infectivity in rice plants since it plays a role in cell-to-cell, long distance movement and systemic infection in $O$. sativa. Furthermore, virus encapsidation is necessary prior to long-distance movement (17; N. Kouassi and C. Brugidou, unpublished results).

Stability. RYMV particles are known to be extremely stable in various conditions, and the virus can survive for at least a year in leaf tissue stored at $4^{\circ} \mathrm{C}$ in the presence of $\mathrm{CaCl}_{2}$. The virus is not affected by treatment with organic solvents such as chloroform, butanol, or carbon tetrachloride ether $(13,23)$. Capsid structure and biochemical analysis support the notion that $3 \mathrm{D}$ domain swapping increases the stability of RYMV (54). In the absence of divalent cations, Southern cowpea mosaic virus (SCPMV) particles swell and fracture, whereas the expanded form of RYMV is stable. This expanded form of RYMV has been pro- posed as intermediate in the in vivo assembly of virions (49). Anion-exchange chromatography was used to identify three different forms of RYMV from infected plants: an unstable swollen form lacking $\mathrm{Ca}^{2+}$ and basic pH-dependent; a more stable transitional form lacking $\mathrm{Ca}^{2+}$ but acidic $\mathrm{pH}$-dependent; and a $\mathrm{pH}$-independent, stable, compact form containing $\mathrm{Ca}^{2+}$ (18). The increasing stability of RYMV particles in plants during the infection course also has been demonstrated: transitional and swollen forms were abundant during early infection ( 2 weeks postinfection), whereas compact forms increased during later stages of infection. It is suggested that maturation of RYMV particles to compact forms could occur in vesicles or vacuoles (18).

Infectivity. Inoculum prepared from young leaves of 'Sindano' rice plants, harvested 2 weeks after inoculation and dried at room temperature $\left(20^{\circ} \mathrm{C}\right)$, were still infective 155 days after harvest. Furthermore, inoculum prepared from infected 'Sindano' young leaves previously cut in small pieces and stored above $\mathrm{CaCl}_{2}$ at
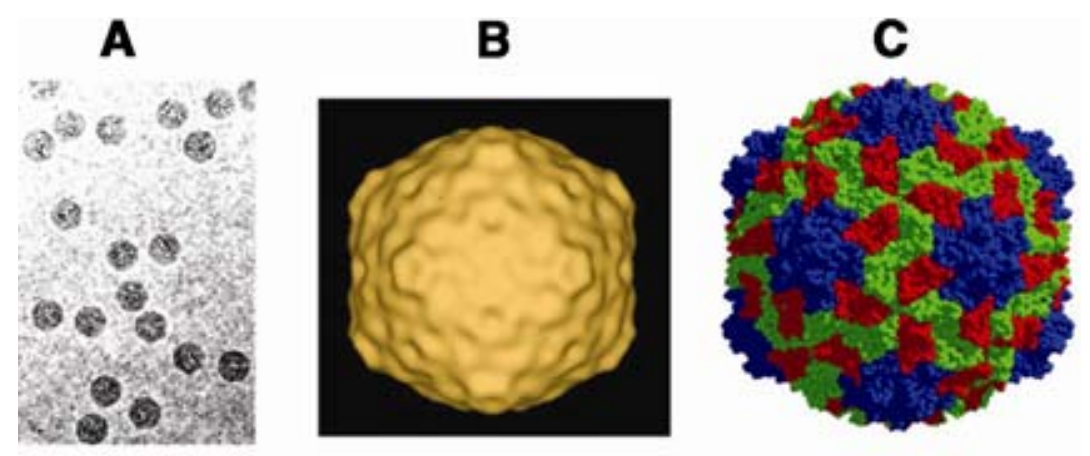

Fig. 4. Structure of Rice yellow mottle virus (RYMV) at different resolutions. A, Electron micrograph of frozen-hybridized native RYMV (Cryoelectron microscopy). B, Threedimensional surface shaded density maps of RYMV derived by cryo-EM (49). C, Spacefilling model of RYMV generated from X-ray crystallography data (54).

$4^{\circ} \mathrm{C}$ was still infective 1 year later (13). The infectivity of sap diluted with $0.01 \mathrm{M}$ phosphate buffer, $\mathrm{pH} 7.0$, was retained for at least 99 days at $20^{\circ} \mathrm{C}$, or up to 260 days at $4^{\circ} \mathrm{C}(13,23)$. Fresh sap from 'Sindano' young leaves harvested 2 to 3 weeks after inoculation with RYMV was still infectious at a dilution of $10^{-10}$, whereas sap from 'Sindano' plants harvested 4 to 5 days after inoculation with RYMV remained infectious at dilution $10^{-6}$ only. However, heating sap at $65^{\circ} \mathrm{C}$ for $10 \mathrm{~min}$ resulted in loss of most infectivity (11).

Histopathology. Virus particles have been observed in systemically infected leaves 7 days after inoculation. At 10 days after inoculation, virus particles were visible in xylem and bundle sheath tissues. Fourteen days after inoculation, most of the virus particles were observed in vascular tissues, and large quantities of virions were dispersed in vessel elements. Also, the virus spread from vascular cells in upper leaves to the epidermis within 14 days after infection. However, the virus particles were found to be most abundant in the vascular tissues, in parenchyma phloem, in xylem cells, and in the companion cells. Particles were found individually, as aggregates, or as crystalline forms in the cytoplasm and the vacuoles of infected cells (18). Virus particles also were seen in mature xylem around, as well as inside, the primary wall. Vesicles containing virus particles have also been found, suggesting that the virus could move from cell to cell inside vesicles (48).

The nucleolus of infected cells enlarges and occupies almost the whole nucleus within 14 days after inoculation. Within 21 days after inoculation, some electron dense, fibrillar material and virus particles could be identified in the majority of mesophyll cells. Other cytological changes were found in the chloroplasts of infected mesophyll cells, where the starch grains decrease in size and number. Virus parti-

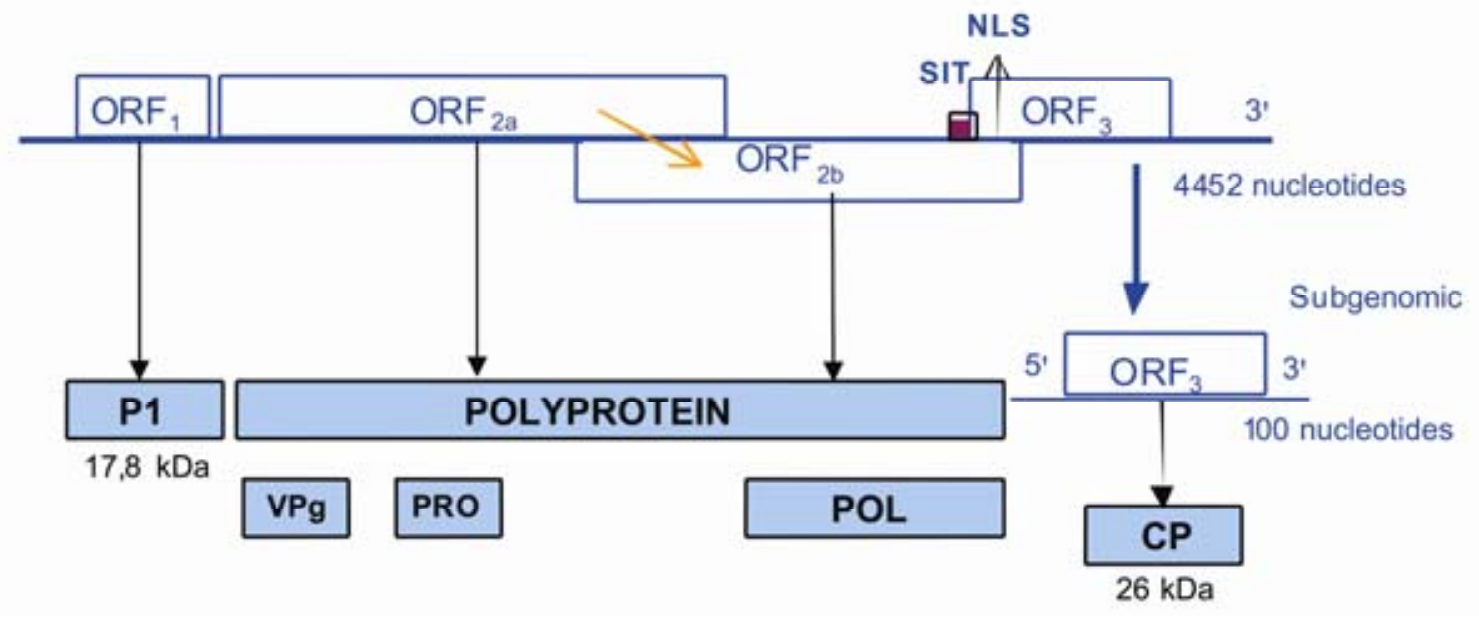

Fig. 5. Rice yellow mottle virus (RYMV) genomic organization: ORF1 (nucleotides [nt] 81 to 554) encodes a protein called P1 of 17.8 $\mathrm{kDa}$, the movement protein of the virus. ORF2a (nt 609 to 2426) and ORF2b (nt 2093 to 3607) encode both for a polyprotein of 110.7 kDa containing a putative VPg, helicase, protease, and polymerase; ORF3 (nt 3447 to 4166 ) codes for the coat protein of 26 kDa. 
cles grouped into paracrystalline arrangements delimited by the tonoplast were found in the vacuole of infected cells. The most dramatic changes induced by RYMV occurred in the cell walls of parenchyma and mature xylem cells, causing disorganization of the middle lamellae wall. This observation may support the hypothesis that virus particles move into metaxylem tissues through walls (48).

\section{Isolate Variability and Distribution}

The serological relationships among RYMV isolates were first studied immunologically with polyclonal antibodies on five isolates collected from the Ivory Coast (CI), Sierra Leone (SL), Niger (Nr), Kenya $(\mathrm{K})$, and Nigeria (Ni) $(22,39)$. Variability also was assessed with monoclonal antibodies (MAbs A, C, D, E, and G) on 127 RYMV isolates collected from 10 countries in Africa. This study revealed five major serotypes named S1 (17 isolates), S2 (79 isolates), S3 (13 isolates), S4 (9 isolates), and S5 (2 isolates) (20,50). Comparison of molecular and immunological typing of isolates of RYMV was performed by D. Fargette (20). The molecular typing was based on the sequences of the ORF4 coding for the $\mathrm{CP}$ and the ORF1 coding for the movement protein $\mathrm{P} 1$. Results showed that molecular typing is consistent with immunological typing but more discriminating. Both typings distinguish the five major strains as above (S1, S2, S3, S4, S5). The strains S1, S2, and S3 are composed of the West African isolates, and S4 and S5 contain isolates from East Africa. S1 is mostly composed of isolates from Côte d'Ivoire, Mali, and Nigeria; S2 is constituted of isolates from Côte d'Ivoire, Mali, Guinea, Burkina Faso, and Ghana; S3 is composed of isolates from Sierra Leone. The S2 strain was numerically predominant in Côte d'Ivoire. In contrast, S1 was predominant in the neighboring countries, Burkina Faso, Ghana, Mali, and Nigeria (44,45). The S4 strain contains isolates from Madagascar, Tanzania, and Kenya, whereas S5 contains isolates from Tanzania only.

The total molecular divergence (with amino acids or nucleotides) is about $14 \%$ $(3,50)$. In the West African strains (S1, S2, and $\mathrm{S} 3$ ), divergence is not more than $6 \%$. West/Central African isolates with up to 9\% divergence belonged to a monophyletic group, whereas the East African isolates (strains S4 and S5), with up to $13 \%$ divergence, fell into distantly related groups. These results suggest that RYMV appeared for the first time in East Africa, and later, in West Africa. The West African situation was consistent with strains having large and overlapping distribution, with virus adaptation to savanna, forest, and other ecological conditions. In contrast, the East African situation, as exemplified by Tanzania with numerous physical barriers, sug- gested that strains resulted from divergence under isolated conditions (3).

All the isolates have the same size of 239 aa, except two strains from Tanzania (Tz2, Tz3), which have an extra alanine at the position 60. Some essential domains, such as the nuclear-targeted sequence and the calcium binding sites, were conserved among the 40 RYMV isolates. Changes of amino acids in the bipartite nuclear targeting sequence motif and around conserved positions 151 to 154 of the $\mathrm{CP}$ gene have been associated with difference in pathogenicity. Two amino acids, at positions 115 (alanine versus threonine) and 191 (valine to threonine), consistently discriminated between the major serotypes; these positions were located in antigenic sites recognized by discriminating monoclonal antibodies (20).

\section{Pathogenicity}

A significant relationship was found between symptom intensity and yield losses. However, yield losses allowed better discrimination among isolates and varieties' responses to RYMV infection than did symptom expression or plant height. Large differences in pathogenicity were observed among isolates when inoculated on different cultivars. Yield loss ranged from 1 to $49 \%$ in Ita 212 and from 10 to $78 \%$ in Ngoyumaboi (depending on the isolates). However, no significant isolate effects were found with some partially resistant varieties (Tox3211, Fkr27) and a highly susceptible variety Wita8 (45).

With most differential varieties, responses were not specific for serological strains, with the exception of the japonica variety Idsa6, in which the $\mathrm{S} 2$ isolates always induced higher yield losses than S1 isolates (45). Recently, using doubleantibody sandwich-enzyme-linked immunosorbent assay (DAS-ELISA), a differential set of eight varieties (Gigante, Bouaké189, Faro11, Morobérékan, Lac23, ITA305, PNA647, F4-56, and H232-44-11) for RYMV pathotype characterization in West and Central Africa was established at WARDA. A hypervirulent isolate from Odienné (Côte d'Ivoire) was able to infect all varieties except Gigante, whereas a hypovirulent isolate from Korhogo (Côte d'Ivoire) infected only Bouaké189, which is known as susceptible (70).

\section{Resistance}

Natural resistance. Screening for resistance to RYMV has been performed for years on rice varieties from different geographical origins and from the two cultivated rice species, $O$. sativa and $O$. glaberrima $(8,9,24-26,47,56)$. Responses to the virus have shown a large variability depending on genotype, but also on screening conditions (such as environment, climatic conditions, severity of inoculation, and resistance evaluation methods). Three kinds of responses to RYMV have been distinguished. A highly susceptible response has been observed in varieties such as BG90-2, Bouaké189, and IR64, varieties widely cultivated in West Africa. These highly susceptible varieties are generally from the indica subspecies of $O$. sativa and are adapted to lowland and irrigated cultivation, where the disease is prevalent. Other cultivars and varieties, such as Moroberekan, Azucena, LAC-23, IRAT13, and OS-6, expressed a partial resistance. Depending on the test severity, they expressed no symptoms or mild symptoms, but the virus was detectable using a serological test. These partially resistant varieties are from the japonica subspecies of $O$. sativa and are adapted to upland cultivation. Fomba (25) and Awoderu et al. (10) noted that a majority of these varieties are of particular interest for breeding, as they also express stable resistance to rice blast disease. A continuum of response can be observed between the highly susceptible varieties and the partially resistant ones. The last kind of response to RYMV inoculation is high resistance, found so far in one variety of $O$. sativa, Gigante, and some accessions of $O$. glaberrima, including Tog5681 (41). This resistance is of particular interest in breeding, but no variety is yet commercially available that has both high resistance and other good agronomic traits.

Genetic basis of resistance. Research is underway at IRD Montpellier (France) using molecular markers to identify genes of partial and high resistance to RYMV. The genetic analysis of partial resistance was based on QTL mapping in a doubledhaploid population derived from the cross between a susceptible indica variety and a partially resistant japonica one, IR64 $\times$ Azucena. For this study, disease impact on plant morphology and development, symptoms, and virus content were evaluated either in field conditions or in a growth chamber. RYMV partial resistance was found to be under a polygenic determinism, and seven chromosomal fragments were found to be involved in resistance $(5,28)$. For most, the favorable allele came from the resistant parent Azucena. Two major QTLs have been identified on chromosomes 1 and 12: they have been detected in different environments and using different resistance criteria, and they explained up to $30 \%$ of resistance (5). The QTL of chromosome 12 also is involved in a complementary epistasis with a region of chromosome 7 explaining $36 \%$ of virus content (53). A relationship between resistance and plant architecture and development was suggested by phenotypic correlation and colocalization of QTLs. This relationship could explain, at least partially, the moderate resistance level generally observed in upland japonica varieties. In contrast, the QTL of resistance mapped on chromosome 12 was found to be independent of plant morphology, making it a 
particularly good candidate for introgression into indica varieties. A near-isogenic line approach has been developed, and the effect of QTL of chromosome 12 and its interaction with a locus on chromosome 7 has been confirmed in an IR64 genetic background (4). The fine mapping and positional cloning of this major QTL is underway at IRD.

The genetic basis of the high resistance of the varieties Gigante (O. sativa) and Tog5681 (O. glaberrima) also has been studied through crosses with the susceptible variety IR64. It has been identified as monogenic and recessive, and the same locus is involved in both varieties (41). The resistance gene has been mapped on the long arm of chromosome 4 , between microsatellite markers RM252 and RM273 (6). The fine physical mapping and the analysis of candidate genes is underway at IRD. Data on the genetic divergence between the two cultivated rice species suggested that two different alleles are present in Gigante and Tog5681.

Hypothesis on resistance mechanisms. The partial resistance character was first studied through evaluation of the partially resistant Azucena variety and the highly susceptible IR64 variety. For this purpose, symptom expression, distribution, and accumulation of the viral $\mathrm{CP}$ and nucleic acid were studied in inoculated leaves and in systemically infected leaves (32). Resistance was first apparent as delayed virus detection and accumulation at the whole plant level. Fifteen days after inoculation, in controlled conditions, the resistance was less apparent since viral RNA replication occurred similarly in the two cultivars. In addition, a tolerance was observed, as symptom expression appeared 4 weeks after inoculation for Azucena instead of 2 weeks for IR64, and was less pronounced in Azucena despite similar virus contents. At the tissue level, partial resistance of Azucena was associated with a delayed detection of virus in the bundle sheaths (mestomes), and 2 weeks after inoculation, when the resistance declined, virus invasion of the mestome was observed. According to Ioannidou et al. (32), partial resistance of Azucena could be due to an impaired cell-to-cell movement of the virus through the mestome. Similar experiments were performed on a near-isogenic line to IR64 but possessing the allele of Azucena at the QTL of chromosome 12 (33). The data indicated that the QTL of chromosome 12 is implicated in a delay of about 1 week in virus accumulation, but not in tolerance.

High resistance was studied by comparing resistant varieties Gigante (O. sativa indica) and Tog5681 (O. glaberrima) to different $O$. sativa and $O$. glaberrima susceptible or partially resistant varieties (42). Coat protein or viral RNA was detected between 5 and 7 days postinoculation in all the varieties tested except Gigante and
Tog5681, in which no infection was observed up to 64 days postinoculation. The result was identical when virus was inoculated into either 10 or 20 days postgermination plants. However, comparison of viral RNA accumulation in protoplasts and plants suggested that resistance in Tog5681 and Gigante was not due to inhibition of virus replication but either to subsequent events like translation efficiency or to the failure of cell-to-cell movement (42).

Recently, genomic approaches to RYMV responsive gene analysis showed that the interactions between RYMV and its host are highly complex in both susceptible and partially resistant rice cultivars. In addition, transcriptome and proteome analysis identified deregulation in metabolic and photosynthetic pathways $(67,68)$.

Breeding. The control of RYMV by conventional breeding for resistance was initiated in 1978 by IITA, and by CNRA and WARDA in the mid-1980s. Several rice varieties from $O$. sativa or $O$. glaberrima have been used in order to diversify the sources of resistance. IITA experimented with transfer of resistance from $O$. glaberrima accessions Tog5674 and Tog5681 into lowland Oryza sativa varieties (ITA212, ITA22, ITA304, and ITA306) and has found some improvement in agronomic traits as well as resistance to RYMV. IITA also crossed the two parents, Moroberekan, a partially resistant variety, and ITA230, a high-yielding variety but highly susceptible to RYMV (31).

The recessive, monogenic high resistance to RYMV, identified in Gigante and Tog5681, can be used in breeding programs more easily than the polygenic partial resistance gene. However, high resistance genes are known to be frequently overcome by pathogens (27). Recently, the two types of resistance to RYMV have been challenged in host passage experiments. The high resistance of Gigante or Tog5681 and the partial resistance of Azucena broke down after serial inoculations. In addition, the presence of natural RYMV isolates able to break host resistance has been observed (36). Therefore, additional sources of resistance with different genetic determinants should also be found, to increase the stability and durability of the resistance (21).

Control by genetic engineering. Because RYMV is an icosahedral and RNA positive strand virus, it was supposed to have suitable characteristics to apply RNA-mediated resistance and coat proteinmediated resistance (CP-MR). This strategy of RNA-mediated resistance has been developed for RYMV at Sainsbury Laboratory (14). In this approach, widely grown, RYMV-susceptible varieties Bouake189, ITA212, and BG90-2 have been transformed with construct encoding a fragment of the RNA-dependent RNA polymerase of RYMV. Twelve fertile independent transgenic lines were inoculated with RYMV particles at $80 \mathrm{ng}$ per plant. Eleven transgenic highly resistant lines from Bouake189 were selected. Further experiments proved that resistance was demonstrated against low and high dose of virions. Based on these features, the authors considered that the mechanism involved in this resistance is the RNA homologydependent resistance (52).

The CP-MR strategy has been developed in the United States (15). For this approach, the japonica rice TP309 and the indica rice BG90-2 varieties were transformed by particle bombardment. TP309 transgenic rice plants expressing wild-type CP (wt), deleted CP (NLS.CP), CP mRNA, or antisense CP mRNA of the RYMV-CI1 have been selected (37). Two-week-old transgenic $\mathrm{T} 2$ plants were challenged with RYMV particles at $100 \mathrm{ng}$ per plant (N. K. Kouassi, unpublished results). Two different types of reaction to RYMV inoculation were observed: most of the plants expressing antisense CP mRNA and a few plants expressing only mRNA exhibited a delay of up to a week for infection and replicated the virus at a low level compared with the nontransgenic TP309; whereas plants expressing RYMV wild-type CP and deleted $\mathrm{CP}$ replicated the virus at the highest rate. These results suggested that the transgenic $\mathrm{CP}$ produced in the plants acts as an enhancer of virus replication of RYMV, whereas antisense $\mathrm{CP}$ induced moderate resistance (N. K. Kouassi, unpublished results).

All the transgenic lines have been tested in the greenhouse. Before open-field testing, these transgenic plants obtained by different methods need to be inoculated with the virus in controlled conditions, along with resistant varieties or cultivars such as Azucena, Gigante, and Tog5681, to evaluate the level and durability of this resistance.

\section{Future Prospects}

Today, cultural practices and prophylactic methods help reduce the negative impact of RYMV in rice production. However these methods have to be combined with resistance breeding to be more efficient. Partial and high resistance genes, used alone or in pyramiding approaches, are of particular interest in breeding new varieties. Already, progress in the selection process of resistant varieties has been achieved. The isolation of natural resistance genes and a better comprehension of RYMV epidemiology and molecular interactions with insect vectors and host plants will help both in optimizing prophylactic methods and increasing the durability of resistance genes. Indeed, resistance-breaking isolates have been found; their prevalence in the fields and their competitiveness will be evaluated. In addition, genomic studies with combined transcriptome and proteome approaches are currently developed to identify plant genes and proteins involved in the virus cycle. 


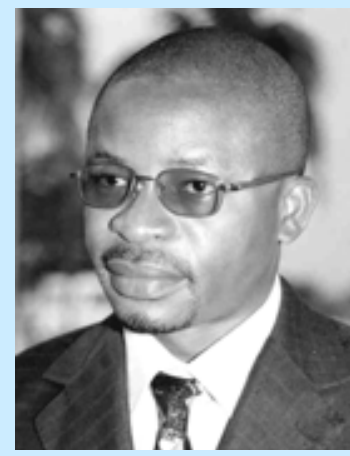

N. K. Kouassi

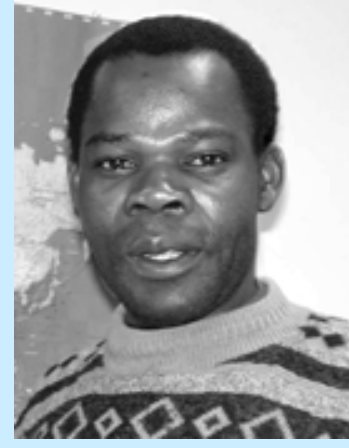

P. N'Guessan

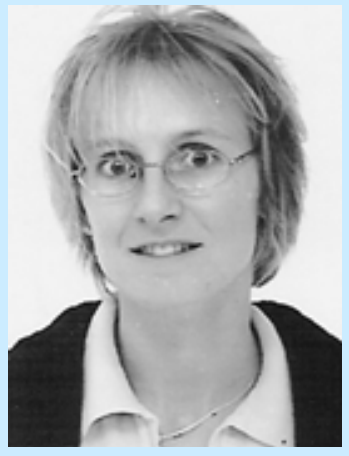

L. Albar

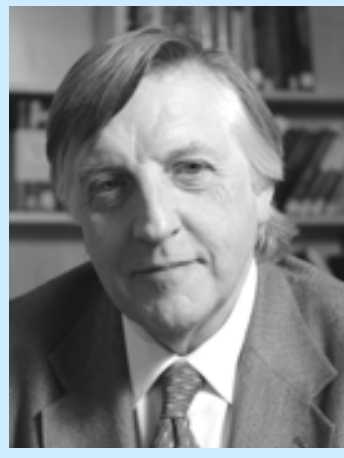

C. M. Fauquet

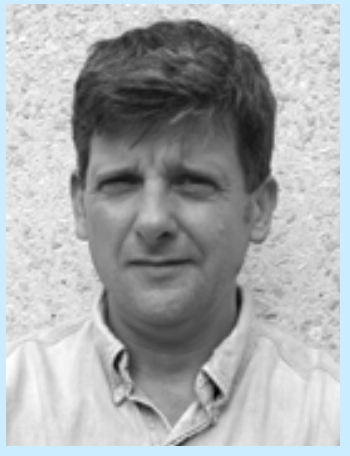

C. Brugidou
Dr. Kouassi is a virologist at Centre National de Recherche Agronomique (CNRA). He received his Ph.D. degree in molecular virology from the University of Montpellier II (France) in 1993. In 1994, he joined the International Laboratory for Tropical Agricultural Biotechnology, The Script Research Institute (ILTAB/TSRI), La Jolla, CA, USA, to work on RYMV genetic engineering program. This postdoctoral position was sponsored by the Rockefeller Foundation Fellowship. He worked on the RYMV coat protein mediated resistance strategy in rice for 3 years. He returned to Côte d'Ivoire in 1997 and has been working at IDEFOR/DPO in crop protection. In 1999, he was appointed at CNRA and is currently the head of the molecular virology unit of the biotechnology laboratory. His research interests include epidemiology and molecular characterization of RYMV and identification of other diseases of cultivated plants. $\mathrm{He}$ is also seeking gene candidates for resistance in RYMV.

Dr. Placide N'Guessan was a virologist and rice project leader at CNRA. He received his Ph.D. degree in pathology and agronomy from Ecole Nationale Supérieure Agronomique de Montpellier (ENSAM) in 1999. Since 1997, he worked on RYMV in collaboration with IRD, on RYMV diversity, pathogenicity, and evolution in Côte d'lvoire. He was the first phytovirologist in Cote d'lvoire to work in the fields and in the laboratory, sharing his research time between Côte d'lvoire and France. In 2003, during the last civil war in Côte d'Ivoire, Dr. N'Guessan was killed while trying to escape from a fighting area.

Dr. Albar is a scientist at the Research Institute for Development (IRD), Montpellier, France. She received an M.S. in plant pathology in 1994 and a Ph.D. in plant biology, option plant pathology, in 1998, from the University of Paris XI-Orsay. Her research focused on the genetic basis of natural resistance of plants against pathogens, in particular in the interaction rice/RYMV. She developed QTL analysis approaches and positional cloning on major resistance genes and QTLs.
Dr. Claude Fauquet, a leading expert on virus taxonomy and on the biological diversity and control of plant viruses, is director of ILTAB, located at the Donald Danforth Plant Science Center in St. Louis, MO, research director at IRD (formerly ORSTOM), and adjunct professor at the University of Missouri campuses in St. Louis and Columbia. He obtained his academic degrees from the University Louis Pasteur of Strasbourg in France. Prior to co-founding ILTAB at The Scripps Research Institute with Dr. Roger Beachy in 1991, Dr. Fauquet was stationed in Ivory Coast, West Africa, where he worked for 14 years. Currently, Dr. Fauquet leads ILTAB with the goal of transferring plant biotechnology to developing countries. ILTAB's research focuses on the control of plant viruses, particularly geminiviruses, in important food crops such as cassava, tomato, and sweetpotato through the use of diverse strategies including gene silencing. Dr. Fauquet also dedicates his efforts toward launching the Global Cassava Partnership for Genetic Improvement to help this important food staple.

Dr. Brugidou is a physiologist and molecular virologist at IRD, a French research institute for developing countries. He received an M.S. and Ph.D. in plant physiology and biochemistry from the University of Sciences of Paris VI, and was research scientist from 1992 to 1999 at ILTAB, directed by C. M. Fauquet and R. N. Beachy. Presently, he is one of the principal investigators on RYMV research at IRD in Montpellier (France). His current research focuses on the molecular interactions between rice and RYMV to elucidate the mechanisms controlling sensitivity, tolerance, and the resistance of rice to the virus. $\mathrm{He}$ is using transcriptomic and proteomic approaches to survey the deregulation of the cellular genes very early in infection. $\mathrm{He}$ is also developing a biochemistry-proteomic-bioinformatic combined approach to identify the cellular host proteins interacting with the viral proteins. 


\section{Acknowledgments}

CNRA, IRD (ex-ORSTOM), a French Scientific Research Institute for Development, and the Rockefeller Foundation supported the publication of this article. We thank N. Taylor and D. Fargette for critical review of the manuscript, and B. N. Singh for critical review of Table 1. We also thank $\mathrm{N}$. Opalka and M. Yeager for providing electron microscopy pictures for the panel presented in Figure 4.

\section{Literature Cited}

1. Abo, M., Alegbejo, M., Sy, A., and Misari, S. 2000. An overview of the mode of transmission, host plants and methods of detection of rice yellow mottle virus. J. Sustain. Agric. 17:19-36.

2. Abo, M., Sy, A., and Alegbejo, M. 1998. Rice yellow mottle (RYMV) in Africa: Evolution, distribution, economic significance and sustainable rice production and management strategies. J. Sustain. Agric.11:85-111.

3. Abubakar, Z., Ali, F., Pinel, A., Traoré, O., N'guessan, P., Notteghem, J.-L., Kimmins, F., Konaté, G., and Fargette, D. 2003. Phylogeography of rice yellow mottle virus in Africa. J. Gen. Virol. 84:1-11.

4. Ahmadi, N., Albar, L., Pressoir, G., Pinel, A., Fargette, D., and Ghesquière, A. 2001. Genetic basis and mapping of the resistance to rice yellow mottle virus. III. Analysis of QTL efficiency in introgressed progenies confirmed the hypothesis of complementary epistasis between two resistance QTLs. Theor. Appl. Genet. 103:1084-1092.

5. Albar, L., Lorieux, M., Ahmadi, N., Rimbault, I., Pinel, A., Sy, A., Fargette, D., and Ghesquière, A. 1998. Genetic basis and mapping of the resistance to rice yellow mottle virus. I. QTLs identification and relationship between resistance and plant morphology Theor. Appl. Genet. 97:1145-1154.

6. Albar, L., Ndjiondjop, M.-N., Esshak, Z., Berger, A., Pinel, A., Jones, M., Fargette, D., and Ghesquière, A. 2003. Fine genetic mapping of a gene required for rice yellow mottle virus cell-to-cell movement. Theor. Appl. Genet. 107:371-378.

7. Ali, F. H., and Abubakar, Z. M. 1995. Incidence of rice yellow mottle virus in Zanzibar. 1st Int. Sympos. rice yellow mottle virus in Zanzibar. Int. Sympos. rice yellow mottle virus (RYMV), 1st. WARDA, Côte d'Ivoire.

8. Attere, A. F., and Fatokun, C. A. 1983. Reaction of Oryza glaberrima accessions to rice yellow mottle virus. Plant Dis. 67:420-421.

9. Awoderu, V. A. 1991. The rice yellow mottle virus situation in West Africa. J. Basic Microbiol. 31:91-99.

10. Awoderu, V. A., Alam, M. S., Thottappilly, G., and Alluri, K. 1987. Ivory Coast rice yellow mottle virus in upland rice. FAO Plant Prot. Bull. 35:32-33.

11. Bakker, W. 1970. Rice yellow mottle, a mechanically transmissible virus disease of rice in Kenya. Neth. J. Plant Pathol.76:53-63.

12. Bakker, W. 1971. Three new beetle vectors of rice yellow mottle virus in Kenya. Neth. J. Plant Pathol. 77:201-206.

13. Bakker, W. 1974. Characterization and ecological aspects of rice yellow mottle virus in Kenya. Agric. Res. Rep. (Wageningen) 829:1-152.

14. Baulcombe, D. C. 1996. Mechanisms of pathogen-derived resistance to viruses in transgenic plants. Plant Cell 8:1833-1844

15. Beachy, R. N., Loesch-Fries, S., and Tumer, N. E. 1990. Coat protein-mediated resistance against virus infection. Annu. Rev. Phytopathol. 28:451-474

16. Bonneau, C., Brugidou, C., Chen, L., Beachy, R. N., and Fauquet, C. M. 1998. Expression of the rice yellow mottle virus $\mathrm{P} 1$ protein in vitro and in vivo and its involvement in virus spread. Virology 244:79-86.

17. Brugidou, C., Holt, C., Ngon A Yassi, M., Zhang, S., Beachy, R. N., and Fauquet, C. M. 1995. Synthesis of an infectious full-length cDNA clone of Rice yellow mottle virus and mutagenesis of the coat protein. Virology 206:108-115.

18. Brugidou, C., Opalka, N., Yeager, M., Beachy, R. N., and Fauquet, C. 2002. Stability of rice yellow mottle virus (RYMV) and cellular compartmentalization during the infection process of Oryza sativa (L). Virology 297:98-108.

19. Fargette, D., Pinel, A., Abubakar, Z., Traoré, O., Brugidou, C., Fatogoma, S., Hébrard, E., Choisy, M., Séré, Y., Fauquet, C., and Konaté, G. 2004. Inferring the evolutionary history of rice yellow mottle virus from genomic, phylogenetic and phylogeographic studies. J. Virol. 78:3252-3261.

20. Fargette, D., Pinel, A., Halimi, N., Brugidou, C., Fauquet, C. M., and Van Regenmortel, M. H. V. 2002. Comparison of molecular and immunological typing of isolates of rice yellow mottle virus. Arch. Virol. 147:583-596.

21. Fargette, D., Pinel, A., Traoré, O., Ghesquière, A., and Konaté, G. 2002. Emergence of resistance-breaking isolates of rice yellow mottle virus during serial inoculations. Eur. J. Plant Pathol. 108:585-591.

22. Fauquet, C. M., and Thouvenel, J. C. 1977. Isolation of the rice yellow mottle virus in Ivory Coast. Plant Dis. Rep. 61:443-446.

23. Fauquet, C. M., and Thouvenel, J. C. 1978. Identification of rice yellow mottle virus in Ivory Coast. Pages 307-310 in: Rice in Africa: Proc. Conf. held at the International Institute of Tropical Agriculture, Ibadan, Nigeria, 7-11 March 1977. I. W. Buddenhagen and G. J. Persley, eds.

24. Fomba, S. N. 1984. Rice disease situation in mangrove and associated swamps in Sierra Leone. Trop. Pest Manag. 30:73-81

25. Fomba, S. N. 1988. Screening for seedling resistance to rice yellow mottle virus in some rice cultivars in Sierra Leone. Plant Dis. 72:641-642.

26. Fomba, S. N. 1990. Rice yellow mottle virus (RYMV) on swamp rice in Guinea. Int. Rice Res Newsl. 15:21.

27. Fraser, R. S. 1990. The genetics of resistance to plant viruses. Annu. Rev. Phytopathol. 28:179-200.

28. Ghesquière, A., Albar, L., Lorieux, M., Ahmadi, N., Fargette, D., Huang, N., McCouch, S. R., and Notteghem, J. L. 1997. A major quantitative trait locus for rice yellow mottle virus resistance maps to a cluster of blast resistance genes on chromosome 12. Phytopathology 87:1243-1249.

29. Hacker, D. L., and Sivakumaran, K. 1997. Mapping and expression of southern bean mosaic virus genomic and subgenomic RNAs. Virology 234:317-327.

30. Hull, R. 1988. The sobemovirus group. Pages 113-146 in: The Plant Viruses: Polyhedral Virions with Monopartite RNA Genomes. R. Koening, ed. Plenum Press, New York

31. International Institute of Tropical Agriculture 1986. Oryza glaberrima as a source of resistance to rice yellow mottle virus. Pages 84-85 in: Annual Report and Research highlights. IITA, Ibadan, Nigeria.

32. Ioannidou, D., Lett, J. M., Pinel, A., Assigbetse, K., Brugidou, C., Ghesquiere, A., Nicole, M., and Fargette, D. 2000. Partial resistance to rice yellow mottle virus in Oryza sativa japonica subspecies is associated with delayed virus accession in the vascular system. Physiol. Mol. Plant Pathol. 57:177-188.

33. Ioannidou, D., Pinel, A., Brugidou, C., Albar, L., Ahmadi, N., Ghesquiere, A., Nicole, M., and Fargettte, D. 2003. Characterisation of the effects of a major QTL of the partial resistance to rice yellow mottle virus using a near-isogenic line approach. Physiol. Mol. Plant Pathol 63:213-221.

34. John, V. T., Thottapilly, G., and Awoderu, V. A 1984. Occurrence of rice yellow mottle virus in some Sahelian countries in West Africa. FAO Plant Prot. Bull. 32:86-87.

35. Konaté, G., Sarra, S., and Traoré, O. 2001. Rice yellow mottle virus is seed-borne but not seed transmitted. Eur. J. Plant Pathol. 107:361364.

36. Konaté, G., Traoré, O., and Coulibaly, M. 1997. Characterization of rice yellow mottle virus isolates in Sudano-Sahalian areas. Arch. Virol. 142:1117-1124

37. Kouassi, N., Brugidou, C., Chen, L., Ngon A Yassi, M., Beachy, R. N., and Fauquet, C. M 1997. Transgenic rice plants expressing rice yellow mottle virus coat protein gene. Int. Rice Res. Notes 22:14-15.

38. Mäkinen, K., Tamm, T., Naess, V., Truve, E. Puurand, U., Munthe, T., and Saarna, M. 1995. Characterization of cocksfoot mottle sobemovirus genomic RNA and sequence comparison with related viruses. J. Gen. Virol. 76:28172825 .

39. Mansour, A. N., and Baillis, K. W. 1994. Serological relationship among rice yellow mottle virus. Ann. Appl. Biol. 125:133-140.

40. Méndez del Villar, M., 2003. Monthly report of the word market of rice. October 2003. InterArroz. Arroz Brasileiro. Online publication.

41. Ndjiondjop, M. N., Albar, L., Fargette, D., Fauquet, C. M., and Ghesquière, A. 1999. The genetic basis of high resistance to rice yellow mottle virus (RYMV) in cultivars of two cultivated rice species. Plant Dis. 83:931-935.

42. Ndjiondjop, M. N., Brugidou, C., Shipping, Z., Fargette, D., Ghesquière, A., and Fauquet, C. M. 2001. High resistance to rice yellow mottle virus in two cultivated rice cultivars is correlated with the failure of cell-to-cell movement. Physiol. Mol. Plant Pathol. 59:309-316.

43. Ngon A Yassi, M., Ritzenthaler, C., Brugidou, C., Fauquet, C. M., and Beachy, R. N. 1994. Nucleotide sequence and genome characterization of rice yellow mottle virus RNA. J. Gen. Virol. 75:249-257.

44. N'Guessan, P., Pinel, A., Caruana, M., Frutos, R., Sy, A., Ghesquiere, A., and Fargette, D. 2000. Evidence of the presence of two serotypes of rice yellow mottle sobemovirus in Côte d'Ivoire. Eur. J. Plant Pathol. 106:167178.

45. N'Guessan, P., Pinel, A., Sy, A. A., Ghesquière, A., and Fargette, D. 2001. Distribution, pathogenicity, and interactions of two strains of Rice yellow mottle virus in forested and savanna zones of West Africa. Plant Dis. 85:5964.

46. Okioma, S. N. M., Muchoki, R. N., Gathuru, E. M., Yadav, S. K., Singh, S. P., and Bhan, V. M. 1983. Alternative hosts of rice yellow mottle virus in the Lake Victoria basin of Kenya. Trop. Pest Manag. 29:295-296.

47. Okioma, S. N., and Sarkarung, M. S. 1983. Screening rice varieties for resistance to rice yellow mottle virus disease in Kenya. Trop Pest Manag. 29:145-147.

48. Opalka, N., Brugidou, C., Bonneau, C., Nicole, M., Beachy, R. N., Yeager, M., and Fauquet, C. M. 1998. Movement of rice yellow mottle virus between xylem cells through pit membranes. Proc. Natl. Acad. Sci. USA 95:3323-3328.

49. Opalka, N., Tihova, M., Brugidou, C., Kumar, A., Beachy, R. N., Fauquet, C. M., and Yeager, M. 2000. Structure of native and expanded sobemoviruses by electron cryo-microscopy and image reconstruction. J. Mol. Biol. 303:197-211

50. Pinel, A., N'Guessan, P., Bousalem, M., and Fargette, D. 2000. Molecular variability of 
geographically distinct isolates of rice yellow mottle virus in Africa. Arch. Virol. 145:16211638.

51. Pinel, A., Trouve, O., Abubakar, Z., Konate, G., and Fargette, D. 2003. Molecular epidemiology of the RNA satellite of the rice yellow mottle virus. Arch. Virol. 148:1721-1733.

52. Pinto, Y., Rossan, A., and Baulcombe, D. 1999. Resistance to rice yellow mottle virus (RYMV) in cultivated African rice varieties containing RYMV transgenes. Nat. Biotechnol. 17:702707.

53. Pressoir, G., Albar, L., Ahmadi, N., Rimbault, I., Lorieux, M., Fargette, D., and Ghesquière, A. 1998. Genetic basis and mapping of the resistance to rice yellow mottle virus. II. Evidence of a complementary epistasis between two QTLs. Theor. Appl. Genet. 97:1155-1161.

54. Qu, C., Liljas, L., Opalka, N., Brugidou, C., Yeager, M., Beachy, R. N., Fauquet, C. M., Johnson, J. E., and Lin, T. 2000. 3D domain swapping modulates the stability of members of an icosahedral virus group. Structure 8:1095-1103.

55. Raymundo, S. A., and Buddenhagen, I. W. 1976. A rice disease in West Africa. Int. Rice Comm. Newsl. 25:58.

56. Raymundo, S. A., and Konteh, I. K. 1980. Distribution, importance, screening methods and varietal reaction to rice yellow mottle disease. Int. Rice Comm. Newsl. 29:51-53.

57. Reckhaus, P. M., and Adamou, I. 1986. Rice diseases and their economic importance in $\mathrm{Ni}-$ ger. FAO Plant Prot. Bull. 34:77-82.

58. Reckhaus, P. M., and Randrianangaly, S. 1990. Rice yellow mottle virus (RYMV) on rice in Madagascar. Int. Rice Res. Newsl. 15:30.

59. Rossel, H. W. 1986. Rice yellow mottle and African soybean dwarf, newly discovered virus diseases of economic importance in West Africa. International symposium on virus diseases of rice and leguminous crops in the tropics, Tropical Agricultural Research Center, Ministry of Agriculture, Forestry and Fisheries, Japan 19:146-153.

60. Rossel, H. W., Ayotade, K. A., Thottapilly, G., Adeoti, A. A., Alluri, K., Alam, M. S., and Zan, K. 1982. A new record of rice yellow mottle virus disease in Badeggi, Nigeria. Int. Rice Comm. Newsl. 31:23-24.

61. Sarra, S., Oevering, P., Guindo, S., and Peters, D. 2004. Wind-mediated spread of rice yellow mottle virus (RYMV) in irrigated rice crops. Plant Pathol. 53:148-153.

62. Sarra, S., and Petres, D. 2003. Rice yellow mottle virus is transmitted by cows, donkeys, and grass rats in irrigated rice crops. Plant Dis. 87:804-808.

63. Sehgal, O. P., AbouHaidar, M. G., Gellatly, D. L., Ivanov, I., and Thottappilly, G. 1993. An associated small RNA in rice yellow mottle sobemovirus homologous to the satellite RNA of lucerne transient streak sobemovirus. Phytopathology 83:1309-1311.
64. Tamm, T., and Truve, E. 2000. Sobemoviruses. J. Virol. 74:6231-6241.

65. Taylor, D. R. 1989. Resistance of upland rice varieties to rice yellow mottle virus (RYMV). Int. Rice Res. Newsl. 14:11.

66. Traoré, O., Pinel, A., Fargette, D., and Konaté, G. 2001. First report and characterization of Rice yellow mottle virus in Central Africa. Plant Dis. 85:920.

67. Ventelon-Debout, M., Delalande, F., Brizard, J.-P., Diemer, H., Van Dorsselaer, A., and Brugidou, C. 2004. Proteome analysis of cultivar-specific deregulations of Oryza sativa indica and $O$. sativa japonica cellular suspensions undergoing rice yellow mottle virus infection. Proteomics 4:216-225.

68. Ventelon-Debout, M., Nguyen T. T. H., Wissocq, C., Berger, M., Laudie, M., Piégu, B Cooke, R., Ghesquière, A., Delseny, M., and Brugidou, C. 2003. Analysis of the transcriptional response to rice yellow mottle virus in fection in Oryza sativa indica and japonica cultivars. Mol. Gen. Genet. 270:253-262.

69. Voinnet, O., Pinto, Y. M., and Baulcombe, D. 1999. Suppression of gene silencing: A general strategy used by diverse DNA and RNA viruses of plants. Proc. Natl. Acad. Sci. USA 23:14147-14152.

70. WARDA. 2000. Rice yellow mottle virus. Annual reports features. Consultative Group on International Agricultural Research (CGIAR) online. Online publication. 